Saudi Journal of Business and Management Studies Abbreviated Key Title: Saudi J Bus Manag Stud ISSN 2415-6663 (Print) |ISSN 2415-6671 (Online) Scholars Middle East Publishers, Dubai, United Arab Emirates Journal homepage: https://saudijournals.com/sjbms

Original Research Article

\title{
The Influence of Destination Awareness, Destination Image and Destination Experience on Travel Decision to Baduy Cultural Tourist Destination, Banten
}

\author{
Hafferson Happy Manurung ${ }^{1 *}$, Rina Astini ${ }^{2}$ \\ ${ }^{1}$ Student of Magister Management Program, Mercu Buana University, Jakarta, Indonesia
}

${ }^{2}$ Lecturer of Magister Management Program, Mercu Buana University, Jakarta, Indonesia

DOI: $10.36348 /$ sjbms.2020.v05i10.002

| Received: 12.10 .2020 | Accepted: 26.10.2020 | Published: 29.10 .2020

*Corresponding author: Hafferson Happy Manurung

\section{Abstract}

Baduy tribe is a tribe that lives isolated from the outside world. They live simply blending with nature. Baduy community on structure was divided into two major groups, such as Baduy Dalam and Baduy Luar community. Baduy Dalam has an area of 1,975 hectares with population up to June 2009 was 1,083 people who spread over three villages, while Baduy Luar area covers 3,127 hectares with total population of 10,089 people, consisting of 55 villages. Administratively, the Baduy government is in Banten Province, Indonesia. According to Statistics Indonesia (BPS), tourist visits to Baduy have increased significantly, though they should be borne by strict customary rules that make some tourists uncomfortable. According to those phenomena occurs and the research results towards influencing variables, the authors were interested in carried out the research to find out if destination awareness, image and experience have impact on travel decision to tourist destinations Baduy. The method used was conclusive research design with causal research to examined those hypothesis and link This research were concluded that destination awareness and destination experience has a negative and significant impact on travel decisions while destination image has a positive and significant impact on travel decisions. The author hopes that further research could re-examine those variables studied but in different cultural tourism destinations or re-test the variables that influence travel decisions that have not been tested in this research.

Keywords: Baduy, Cultural Tourist Destination, Awareness, Image, Experience, Travel Decision.

Copyright (C) 2020 The Author(s): This is an open-access article distributed under the terms of the Creative Commons Attribution 4.0 International License (CC BY-NC 4.0) which permits unrestricted use, distribution, and reproduction in any medium for non-commercial use provided the original author and source are credited.

\section{INTRODUCTION}

Baduy tribe is a tribe that lives isolated from the outside world. They lived simply and get along with nature. Baduy community customary area is about $5,101.8$ hectares, which is located in the west of Java Island, around the Kendeng Mountains. In government administration, this area was confirmed as Kanekes Village, Leuwidamar District, Lebak Regency, Banten Province [1]. Baduy community structure was divided into two major groups, namely Baduy Dalam community and Baduy Luar community. Baduy Dalam area has an area of 1,975 hectares with population up to June 2009 was 1,083 people (281 families) spread over three villages, such as the villages of Cikeusik, Cikartawana and Cibeo, while Baduy Luar area covers
3,127 hectares with population of 10,089 or 2,667 households consisting of 55 villages [2].

The major source of livelihood for the Baduy community is dryland rice cultivation. Its cultivation system is shifting cultivation with a fallow period (resting the land) for 5 years. Another way to live by making handicrafts from bamboo, making Koja (bags made of bark), looking for rattan, bananas, fruit and honey, hunting, making roofs from Kirai leaves, making agricultural tools such as machetes. As for baduy women, apart from farming, their activity in their spare time is weaving. For Baduy Luar, apart from these activities, other livelihoods are tapping down to make sugar, farming, planting sengon wood, trading and 
becoming a laborer. The work is carried out solely to fill the needs and not allow to overproducing. Baduy community does not recognize the formal education system or school, adat law which prevent them from attending school, but they are capable to reading and writing also arithmetic by learning from outsiders who come across [2].

The location of Baduy community is an attractive destination for both foreign and local tourists. According to Statistics Indonesia (BPS) Lebak Regency, tourist visits to Baduy tourist destinations have increased significantly, though it is quite difficult to reach Baduy locations, as well as the strict customary rules that regulate community relations with the environment. This phenomenon got the author's attention to analyze those factors which encourage respondents to decide to travel around there.

Based on previous research, the authors found several variables which influence tourists visiting to a tourist destination. The decision of tourist visit to a destination was influenced by destination familiarity [3], was influenced by travel motivation [4], was influenced by destination awareness [5], was influenced by destination experience [6], was influenced by destination image [7], was influenced by electronic word of mouth or e-wom [8], was influenced by travel's blog [9], was influenced by nostalgia [10], was influenced by socio-demographic [11] and was influenced by destination price [12] and also was influenced by destination trust [13]. Through variables that have been researched by previous researchers, the researchers conducted a pre-survey to find out which factors were taken into consideration or encouraged respondents to decide visiting Baduy tourist areas. The results of the pre-survey found that destination awareness and destination image and destination experience variables were the majority variables which influenced the respondent's travel decision.

Based on phenomena above and those previous research studies also the results from pre-survey which mentioned before, the authors were interested in carried out those research over the influence of destination awareness, destination image and destination experience on tourists travel decision to tourist destinations of Baduy Banten. The authors wish that these research results could provide benefits for those concerned academically and practically.

\section{LITERATURE REVIEW \\ Destination Awareness}

Brand awareness consists of recognizing and remembering a brand, where consumers were able to confirm about previous exposure to a brand when branded as a cue [14]. Brand awareness is related to the possibility of consumers remembering and being aware of a brand as is an important and special aspect of brand equity [15]. Giving brand names has done with purpose to increasing awareness and building perceptions about the quality and benefits from an item, service, or destination [16]. In tourism, destination awareness has an important role in tourist travel decisions [17]. The dimensions of destination awareness in this research based on Chi, et al. [5], namely could imagine a tourist destination, knowing the place as a tourist destination, distinguishing of this tourist destinations from others similar, given some of characteristics of a destination which pop up when thinking about travel.

\section{Destination Image}

Brand image is the consumer's perception of a brand, as reflected by the brand associations which exist in consumer memory [14]. Those Associations come in all forms and reflect its product characteristics or aspects that are separate from the product. Related to tourism, a destination image is a belief, idea, and impression which person has about a destination/place [18]. Destination image is the tourist's impression of destination [19]. Destination image is a combination of beliefs, knowledge, feelings and impressions in general, or the feelings that tourists have about a tourist destination [7]. Destination image is a representation of perceptions in the mind of person or group about the beliefs of an impression, prejudice, and emotions they have from a certain destination or place, Al-Azri \& Morrison [20]. The whole image of a tourist destination or place was formed by two types of evaluation, namely perceptual evaluation or cognitive evaluation such as belief and knowledge and affective evaluation in the form of feelings or attachments [7]. The dimensions of the destination image in this research were according to Echtner \& Brent Ritchie in Astini [21] where the destination image has four components, which is functional characteristic attributes include the condition of a tourist attraction, the price level of a tourist attraction, and the condition of the infrastructure. Holistic functional characteristic attributes include conditions of cleanliness, personal safety, ease of access. Psychological characteristic attributes include human friendliness, environmental sustainability. Psychological-holistic characteristic attributes include the general feeling of visitors, tourism development.

\section{Destination Experience}

A tourist destination is a tourism ecosystem which includes various tourism products and services that offer experiences for tourists, where every aspect offered by tourist destination will contributes to the destination experience [22]. Destination experience could affect the image which felt after the visit, where the current situation was interpreted by comparing with last experiences [23]. Past experiences may be more important than information obtained from external sources because individuals tend to emphasize more on destination experiences. Destination experiences which gave a positive impression and enjoyment for visitors, will have many positive impacts on individuals, communities, businesses or even community welfare 
[4]. The dimension which, according to Lee \& Jan [17], namely knowledge, consisting of experience makes me more knowledgeable, real learning experience, stimulates my curiosity to learn new things. Entertainment, consisting of funny experience activities, charming experience activities, entertaining experience activities. Beauty, consisting of very attractive, detailed design, fun to be here, can feel real harmony. Escape, consisting of feeling like I could play a different character here, this experience made me imagine being someone else, completely breaking out of my daily routine, feeling like I was in a different time or place.

\section{Travel Decision}

Purchasing decision process consists of five stages, such as knowing needs, seeking information, evaluating alternatives, purchase decision, and postpurchase behavior [24]. In this research the dimensions used was according to Kotler \& Armstrong [24], such as need recognition, Information Search, which is conducting information searches through various channels to find what is needed, such as personal, public, commercial and experiential information. Evaluation of Alternatives, namely evaluating before making decisions to satisfy needs. Purchase Decision, which is to rank the products available or make a priority scale and then make decisions. Post-purchase Behavior, namely assessing the satisfaction obtained by comparing the expectations with performance of the product bought.

\section{Conceptual Model}

The conceptual model proposed in this research could be seen as below.

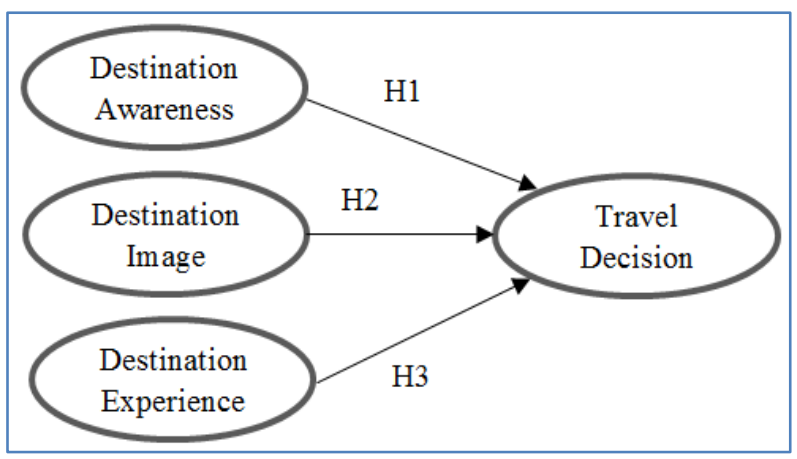

Fig-1: Conceptual Model
H1: Destination awareness variable has a positive and significant impact on tourist decision variable to visit Baduy tourist destinations.

H2: Destination image variable has a positive and significant influence on tourist travel decision to Baduy tourist destinations.

H3: Destination experience variable has a positive and significant influence on the tourist travel decision variable to visit Baduy tourist destinations.

\section{RESEARCH METHODS}

In this research, Researchers used conclusive research design with causal research type. Causal research is a type of conclusive research that has main purpose to gather evidence of cause and effect (causal relationship). The independent variables were destination awareness, destination image, destination experience and dependent variable was travel decision. Researchers used a Likert scale. The population was visitors who have visited Baduy in the last 5 years. Determination of the total of representative samples depends on the number of indicators multiplied by 5 to 10 [25]. These research designs have 37 indicators, so the number of samples taken was 185. Sampling method was carried out by purposive sampling method, which is sampling based on certain considerations and should represent the population which studied [26]. Data collection techniques used were field research or questionnaires. Then it will be analyzed by Structural Equation Model (SEM) with assistance of LISREL 8.80 program to examine those hypothesis.

\section{RESULTS}

\section{Respondent Characteristics}

The characteristics from whole respondents in this research, from a total of 185 respondents, 107 were male respondents and 78 female respondents. There were 4 respondents aged $<20$ years, 7 respondents aged 20-30 years and 174 respondents aged > 30 years. Respondents who had worked as students were 8 respondents, civil servants as many as 5, private employees 114, entrepreneurship 7, and respondents from other professions were 51 .

\section{Validity Test and Reliability Test}

Validity tests were carried out for all statements of each variable and resulting SLF value was higher than 0.5 , therefore all statements were declared valid. Validity test result could be seen as below:

Table-1: Validity Test Result

\begin{tabular}{|l|l|l|l|l|}
\hline Variable & Chi-square & df & p-Value & RMSEA \\
\hline Destination Awareness & 64.62 & 5 & 0.00000 & 0.255 \\
\hline Destination Image & 567.05 & 35 & 0.00000 & 0.287 \\
\hline Destination Experience & 55.20 & 9 & 0.00000 & 0.174 \\
\hline Travel Decision & 434.42 & 27 & 0.00000 & 0.286 \\
\hline
\end{tabular}

Reliability tests were carried out through all variable and resulting $\mathrm{CR}$ value was higher than 0.7 , therefore all variable were declared reliable. Reliability test result could be shown as below: 
Table-2: Reliability Test Result

\begin{tabular}{|l|l|l|l|}
\hline Variable & CR Value & VE Value & Conclusion \\
\hline Destination Awareness & 0.88 & 0.60 & Reliable \\
\hline Destination Image & 0.94 & 0.60 & Reliable \\
\hline Destination Experience & 0.96 & 0.71 & Reliable \\
\hline Travel Decision & 0.93 & 0.61 & Reliable \\
\hline
\end{tabular}

\section{Structural Model Fit Test (T Test)}

Structural Model Fit Test (T-test) The overall results from fit of model it could be seen through table below, where the results obtained were Chi-Square =
2548.23, $\mathrm{df}=569, \mathrm{P}$-Value $=0.00000$, RMSEA $=$ 0.080 . Fit model value shows a good value, which is a good fit, meaning that overall observance value shows a good fit value.

Table-3: Fit Test Results for the Structural Model Research Model

\begin{tabular}{|l|l|l|l|}
\hline GOF Measures & Fit Target & Estimation Result & Fit Level \\
\hline RMSEA & $\leq 0.08$ & 0.080 & Good Fit \\
\hline NFI & $\geq 0.90$ & 0.92 & Good Fit \\
\hline NNFI & $\geq 0.90$ & 0.92 & Good Fit \\
\hline CFI & $\geq 0.90$ & 0.93 & Good Fit \\
\hline IFI & $\geq 0.90$ & 0.93 & Good Fit \\
\hline RFI & $\geq 0.90$ & 0.90 & Good Fit \\
\hline GFI & $\geq 0.90$ & 0.57 & Bad Fit \\
\hline AGFI & $\geq 0.90$ & 0.47 & Bad Fit \\
\hline
\end{tabular}

\section{Research Hypothesis Examination}

After obtaining structural model with a good value of Goodness of Fit, then as further step was to assess the hypothesis. The significance value $(\alpha)$ used was 0.05 or $5 \%$ with $\mathrm{t}$-value of $\geq 1.96$ [27]. These hypothesis test results shown in below:

Table-4: Hypothesis Testing Results

\begin{tabular}{|l|l|l|}
\hline Structural Path & T-Values & Conclusion \\
\hline Destination Awareness $\rightarrow$ Travel Decision & -3.74 & Negative Significant \\
\hline Destination Image $\rightarrow$ Travel Decision & 4.84 & Positive Significant \\
\hline Destination Experience $\rightarrow$ Travel Decision & -2.34 & Negative Significant \\
\hline
\end{tabular}

From these statistical test, the results obtained for destination Awareness had a negative and significant influence over travel decision, this indicated by $\mathrm{t}$-value was below 1.96, namely -3.74 , while destination image had a positive and significant impact towards travel decision, This shows by the value above 1.96 was 4.84 and as for destination experience it has a negative and significant effect on travel decision, where its value below 1.96 , namely -2.34 .

\section{CONCLUSION AND SUGGESTION Conclusion}

Destination awareness has a negative and significant influence on travel decision, meaning if in this research the higher sense of awareness that respondent has ( were this research related to Baduy cultural tourism destinations), the more it will make respondents would think again about visiting Baduy tourist destinations. Destination image has a positive and significant influence on travel decisions, meaning if the image of Baduy cultural tourism destinations was the main factor which affected the respondent's decision to visit. Destination experience has a negative and significant influence on travel decision, meaning if destination experience or travel experience which felt by respondents after visit Baduy tourist destinations were actually makes respondents think again to decide to return to Baduy tourist destinations.

\section{Limitation and Suggestion}

1) Limitation and Advice for Academics

For further researchers, it is hoped that they could re-examine those variables which used in this research but in different cultural tourism destinations such as Tana Toraja, Dayak or so on. They could also re-evaluation those variables which influence to travel decisions which have not been tested in this research, for example the variables of travel motivation, destination familiarity, and other variables that influence the tourists travel decisions.

2) Suggestions for Baduy Cultural Tourism Managers It is suggested that it should be able to strengthen the branding of Baduy tourist destinations as Banten Cultural Tourism Destinations, for example by promoting the uniqueness of Baduy cultural tourism destinations through social media. It is recommended to created travel posts because the terrain traveled to visit Baduy was quite difficult to reach and takes time, so tourists will not feel worried when they want to make a visit. It is suggested to be able to maintain and improve those 
local beauty and wisdom so the tourists could get more unforgettable experiences while visit.

3) Suggestions for the Banten Province Tourism Office It is recommended that to left alone the nature beauty but could be added with sufficient safety for tourists visit there because the track field to reach Baduy was requires great effort and times besides that, travel posts need to be built so when tourists feel exhausted they can take a break on there. It is very recommended to all stakeholders, both managers and travel agents, strengthen the branding of Baduy cultural tourism and create marketing strategies such as promotion via social media, endorsing travel bloggers via YouTube accounts or other. It is advisable to create a marketing strategy that aimed at allocentric tourist groups or segments, considering if Baduy tourists are more likely to be visited by allocentric segment tourists (adventurers).

\section{REFERENCES}

1. Adimihardja, K. (2000). Orang Baduy di Banten Selatan: Manusia Air Pemelihara Sungai. Atropologi Indonesia, 61.

2. Senoaji, G., (2010). Masyarakat Baduy, Hutan dan Lingkungan (Baduy Community, Forest, and Environment). Jurnal Manusia dan Lingkungan, I7(2), 113-123.

3. Chaulagain, S., Wiitala, J., \& Fu, X. (2019). The impact of country image and destination image on US tourists' travel intention, Journal of Destination Marketing and Management,12, 1-11.

4. Zhang, T., Xiaoxiao, F., Nan, H., \& Youcheng, W. (2019). Exploring the roles of technology, people, and organization in building a tourism destination experience: Insights from the 2nd USA-China tourism research summit and Industry Dialogue. Journal of Destination Marketing \& Management, 12, 130-135.

5. Chi, Hsin-Kuang. (2018). Elements of destination brand equity and destination familiarity regarding travel intention, Journal of Retailing and Consumer Service, 52, 101728.

6. Ferns, Bo H., \& Andrew, W. (2012). Enduring travel involvement, destination brand equity, and travelers' visit intentions: A structural model analysis, Journal of Destination Marketing \& Management, 1(1-2), 2735.

7. Baloglu, S., \& McCleary, K. W. (1999). A model of destination image formation, Annals of Tourism Research, 26(4), 868-897.

8. Jalilvand, R., Samiei, N., Dini, B., \& Manzari, P. (2012). Examining the structural relationships of electronic word of mouth, destination image, tourist attitude toward destination and travel intention: An integrated approach. Journal of Destination Marketing \& Management, 1(1-2), 134-143.

9. Chen, Y.C., Shang, R.A., \& Li, M.-J. (2014). The effects of perceived relevance of travel blogs' content on the behavioral intention to visit a tourist destination. Computers in Human Behavior, 30, 787799.
10. Leong, A., Yeh, S., Hsiao, Y., \& Huan, T. (2014), "Nostalgia as travel motivation and its impact on tourists' loyalty", Journal of Business Research, 68(1), 81-86.

11. Martinez, F.L. (2017). Visual landscape preferences in Mediterranean socio-demographic areas and their influences. Ecological Engineering, 104, 205-215.

12. Dwyer, L., Forsyth, P., \& Rao, P. (2000). The price competitiveness of travel and tourism: a comparison of 19 destinations. Tourism Management, 21, 9-22

13. Mainolfi, G., \& Marino, V. (2017). Destination beliefs, event satisfaction and post-visit product receptivity in event marketing: Results from a tourism experience, Journal of Business Research, 116, 699. 710.

14. Keller, K. L. (2013). Strategic Brand Management: building, measuring, and managing brand equity. 4th edition. Pearson Education, Inc., USA.

15. Tasci, A.D.A. (2018).Testing the cross-brand and cross-market validity of a consumer-based brand equity (CBBE) model for destination brands, Tourism Management, 65, 143-159.

16. Murphy, L., Benckendorff, P., \& Moscardo, G. (2007). Destination brand personality: visitor perceptions of a regional tourism destination. Tourism Analysis, 12, 419-432.

17. Yuan, J., \& Jang, S. (2008). The Effects of Quality and Satisfaction on Awareness and Behavioral Intentions: Exploring the Role of a Wine Festival. Journal of Travel Research, 46(3), 279-288.

18. Crompton, J. L. (1979). An Assessment of the Image of Mexico as a Vacation Destination and the Influence of Geographical Location Upon That Image. Journal of Travel Research, 17(4), 18-23.

19. Fakeye, P. C., \& Crompton, J. L. (1991). Image diff erences between prospective, first time, and repeat visitors to the Lower Rio Grande Valley. Journal of Travel Research, 30(10).

20. Al-Azri, H. I., \& Morrison, A. M. (2006). Measurement of Oman's destination image in the US. Tourism Recreation Research, 31(2), 85-89.

21. Astini, R. (2015). Pengaruh Destination Image, Travel Motivation dan Kualitas Layanan terhadap Kepuasan Pengunjung (Studi Kasus pada Wisatawan Nusantara Muslim di Pantai Carita Pandeglang Banten)". Jurnal Ilmiah Manajemen dan Bisnis, 1(3), 1-6.

22. Gardiner, S., \& Scott, N. (2018). Destination innovation matrix: A framework for new tourism experience and market development. Journal of Destination Marketing \& Management, 10, 122-133.

23. Beerli, A., \& Martin, J. D. (2004). Factors influencing destination image. Annals of Tourism Research, 31(3), 657-681.

24. Kotler, P., \& Armstrong, G. (2012). Principles of Marketing, 14th edition. Prentice Hall. New Jersey.

25. Hair. (2014). Multivariate Data Analysis. Seventh Edition. Pearson Education Limited, Harlow, Essex.

26. Sekaran, U., \& Bougie, R. (2016). Research Methods for Business. A Skill Building Approach, John Wiley and Son, Ltd., West Sussex, UK.

27. Wijanto, S. (2008). Structural Equation Modelling dengan Lisrel 8.8. Graha Ilmu. Yogyakarta. 